\title{
Controlling Foliar Blights of Wheat in the Rice-Wheat Systems of Asia
}

\author{
E. Duveiller, Regional Wheat Pathologist, CIMMYT South Asia, Singha Durbar Marg Plaza, P.O. Box 5186, Kath- \\ mandu, Nepal
}

\begin{abstract}
Duveiller, E. 2004. Controlling foliar blights of wheat in the rice-wheat systems of Asia. Plant Dis. 88:552-556.

Foliar blight caused by Cochliobolus sativus and Pyrenophora tritici-repentis is the main biotic stress of wheat in the rice-wheat systems of South Asia, where it causes, on average, up to $15 \%$ yield loss. Increases in food production have to come from higher and sustainable productivity. It requires a multidisciplinary approach combining novel resistance sources and adapted agronomic practices. Better host plant resistance has been achieved by crossing genetic resistance sources or wild relatives to high-yielding cultivars. Germ plasm improvement methods centered on regional partnerships are now more specifically addressing the needs of warmer areas. Observations in long-term trials underline the increasing role of soil fertility in reducing disease severity. Studies focusing on the effect of stress conditions on disease development increase knowledge about the stability of resistance. This makes breeding more efficient and helps recommend better-adapted crop management practices. The adoption of reduced tillage methods and soil conservation practices imply farmers' direct participation in the research process. Foliar fungicide treatments are not a viable alternative for small farmers, but seed treatment may prove useful as part of an integrated disease management approach based on improved genetic resistance and good agronomy.
\end{abstract}

Foliar blight is the major biotic constraint to wheat in the Gangetic Plains, especially in the rice-wheat system covering 13 million ha. More than 250 million people depend solely on this system for their subsistence. In China, an additional 10 million ha is sown to a rice-wheat sequence, but foliar blight does not significantly impact wheat production there. Possible reasons are better soil fertility resulting from a higher return of organic matter and limited use of fungicide to control Fusarium head scab, an important disease in the Yang Tze River basin. In South Asia, foliar blight is commonly referred to as Helminthosporium leaf blight

Corresponding author: E. Duveiller E-mail: E.Duveiller@cgiar.org

Financial support was provided by DGIC (Directorate General for International Cooperation) of the Belgium Government to CIMMYT allowing conducting research on foliar blight of wheat in South Asia in collaboration with farmers and national research programs scientists.

Paper presented at the "Plant Diseases Impacting Resource-Poor Farmers in Developing Countries" OIP Symposium, APS meeting, Milwaukee, July 30, 2002.

Accepted for publication 1 December 2003.

Publication no. D-2004-0224-010

(C) 2004 The American Phytopathological Society
(HLB) because it often occurs as a complex of spot blotch and tan spot caused by Cochliobolus sativus (Ito \& Kuribayashi) Drechs. ex Dastur and Pyrenophora triticirepentis (Died.) Drechs., respectively. Yield losses are significant and vary depending on sowing time, year, locations, and stress conditions $(1,3,21)$. Estimated losses are $15 \%$ on average, but may reach $34 \%$, as observed in farmers' fields and experimental plots in Nepal in 2002.

Management of HLB has received more attention in recent years because of the urgent need to increase crop productivity and ensure food security in the warmer wheat-growing areas of the Indian Subcontinent. It is vital in less-favorable environments such as the eastern Gangetic plains, which include the Nepalese tarai (lowlands), Bangladesh, and parts of India (in particular Bihar, eastern Uttar Pradesh, and West Bengal). Moreover, concerns have emerged regarding the sustainability of the rice-wheat system in South Asia, its decreasing total factor productivity, and the need to adopt new tillage technologies to produce rice and wheat at a lower cost and in a sustainable manner (12).

The objective of this article is to put into perspective the challenges faced by small farmers, plant pathologists, and other national research program scientists in controlling wheat foliar blight in a changing socioeconomic environment where appropriate, sustainable technologies increas- ingly are being adopted to enhance food production and farmers' social well-being.

Challenges faced by small farmers in the rice-wheat system of the IndoGangetic plains. In contrast to most researchers and extension agents who specialize in one disease or one crop, farmers everywhere deal with complex situations, and South Asia is no exception. Small farmers across the different transects of the Gangetic plains face a range of challenges that are often very site specific. Addressing these needs requires a series of appropriate technological options that best suit the circumstances and conditions (9). From the Nepalese valleys in the Himalayan foothills, where access to modern, diseaseresistant wheat cultivars is still limited, to the more favorable western plains of India, where profitable basmati rice is harvested late, or to the lower eastern plains, where flooding may delay the timely sowing of wheat, very diverse cropping system production constraints occur. Farmers face difficulties that vary depending on their socioeconomic conditions. Although they are natural innovators, farmers are also averse to risk, which affects the adoption rate of new technologies. Smallholders constitute $78 \%$ of India's farmers, yet smallholder families make up more than half of India's hungry and poor (26). Although smallholders owned only $33 \%$ of the total cultivated land in the early 1990s, their contribution to national grain production was $41 \%$. In eastern India (e.g., in eastern Uttar Pradesh), a typical, poor, rice-wheat sharecropping household with two adults and three children cultivates, on average, 0.8 ha of irrigated land (26). In Nepal, a similar family may cultivate less than 0.5 ha.

Wheat yields average about $2.8 \mathrm{t} / \mathrm{ha}$ in India but fall below $2 \mathrm{t} /$ ha in Nepal (Table 1). Typically, the kharif (monsoon) rice crop is followed by a wheat crop, and sometimes a short vegetable crop. Wheat has to be sown immediately after the rice harvest if subsequent wheat yields are to be satisfactory. Numerous constraints may delay rice seeding and transplanting (late monsoon onset, labor shortages, water shortages, excessive puddling, and shortage of inputs, including energy), and, later, the rice harvest. A late rice harvest translates into late wheat sowing and reduces yield because wheat flowering coincides 
with the hot winds or high temperatures that occur at the end of the following rabi (winter) season.

Huge advances were achieved in the last 40 years in both rice and wheat as a result of the green revolution (Table 1). However, productivity increases are now more difficult to achieve, and average annual yield growth rate went from $3.1 \%$ in the 1980 s to $1.3 \%$ in the 1990 s. Even though South Asia is currently self-sufficient in wheat and India recently has started exporting surpluses, the region could face a deficit of about 21 million $t$ of wheat grain in 2020 $(12,19)$.

Achieving the needed production increases will require higher productivity, particularly in warmer growing areas where biotic stresses like foliar blights are more important. In these areas, productivity is still low, and yield gaps of 1 to $2 \mathrm{t} / \mathrm{ha}$ between experiment stations and farmers' fields are common. Declining soil productivity (due to low organic matter and excessive reliance on unbalanced applications of mineral fertilizers; the use of nitrogen, at times subsidized, has led to phosphorus mining and potassium decline) is depressing wheat and rice yields and requires new environmentally friendly, resource-conserving techniques. Many resource management technologies are scale neutral (9); thus, poor smallholders gain from their adoption, although the process might be somewhat slower in areas where shareholders constitute a higher percentage of farmers.

\section{The Foliar Blight Complex}

In South Asia, where wheat is grown from mid-November to early April, foliar blight symptoms may appear less than a month after sowing. The disease becomes more evident in mid-February as a result of rising temperatures and heavy dew that may remain in the crop canopy for several hours on foggy winter days. Bipolaris sorokiniana, the anamorph stage of $C$. sativus (only reported to occur in nature in Zambia), is the predominant pathogen associated with foliar blight, although $P$. tritici-repentis, the causal agent of tan spot, is also common (14). Both fungi form a disease complex, though recent field surveys conducted in the Nepalese lowlands suggest that tan spot is largely overlooked (24). Based on symptom observation, it is almost impossible to identify both pathogens with certainty in the field even with the help of a $\times 50$ magnifying lens. Inconsistent reports suggest that Alternaria triticina (Prasada \& Prabhu) also may be associated to foliar blights $(14,17,20)$. However, it is generally accepted that this fungus is a weak minor pathogen that mainly affects old local cultivars, particularly of durum wheat.

After the impressive progress in controlling leaf and stem rusts in modern cultivars, HLB has emerged as the most important disease of second-generation wheat genotypes in warmer areas $(3,13)$. In CIMMYT terminology for classifying wheat-growing areas, foliar blight typically prevails in cropping environments classified as ME-5 and characterized by high relative humidity and a mean minimum temperature above $17^{\circ} \mathrm{C}$ in the coolest month (10). In extremely humid and hot environments, such as the Red River basin in Vietnam, the disease may not allow the growth of wheat as a commercial crop even where land is available after rice cultivation.

B. sorokiniana isolates, unlike rusts, do not show clear virulence patterns and consist of a continuum of strains differing in aggressiveness $(5,14)$. Host-pathogen interactions do not represent more than 1 to $2 \%$ of the variance (11). Hence, these interactions are of little practical relevance, and have only minor, occasional effects on varietal resistance in farmers' fields (27). Still, there is a need to continuously monitor the stability of known host resistance sources and potential genotypeenvironment interactions (G-E; 8). National wheat programs in South Asia and CIMMYT are planting the Helminthosporium Monitoring Nursery on a regional basis to address this concern. The nursery includes parental materials from different geographical origins and genetic background, synthetic hexaploids resulting from crossing tetraploid wheat with $A e-$ gilops squarrosa (syn. Triticum tauschii), and a few advanced lines produced by breeders in South Asia. It currently is tested annually at 10 sites in India, Nepal, and Bangladesh. The disease increases very quickly in the field, and small differences indicating partial resistance need to be observed; therefore, disease evaluation is based on the area under disease progress curve (AUDPC) calculated after a minimum of three field observations $(1,4)$. Until now, results have not suggested that significant genotypes-location interactions exist. Low disease levels are observed in materials from China and genotypes resulting from wide crosses, but the higher resistance observed is not necessarily correlated with higher yields. Earlier materials usually present a higher disease severity (Table 2).

\section{Control Methods}

Breeding for resistance. As indicated, most wheat growers in the eastern regions of South Asia are smallholders and shareholders. Modern fungicides are not available in most areas of the Gangetic plains and their use is not economical; therefore, resistance breeding has been the key approach to control the devastating HLB disease. It is cost effective, environmentally safe, and the cornerstone of increased food security using local resources and knowledge.

Genetic stocks currently are tested at specific hot-spot locations such as Bhairhawa, where the Nepal national wheat program is located, or in Jessore (Bangladesh), to confirm the resistance of parental lines (Table 3). Sources of resistance include wheat materials from Brazil, Zambia, and China. In China, genotypes from Heilongjiang, Sichuan, and the Yang Tze River valley are characterized by a very short and efficient grain-filling period resulting from the warmer conditions that occur at the end of the growing season in these areas. This character may explain a better resistance to HLB; thus, future research on disease resistance needs to address genotype resilience against several

Table 1. Production, area, and yield of rice and wheat in South Asia over the past 40 years ${ }^{\mathrm{a}}$

\begin{tabular}{|c|c|c|c|c|c|c|}
\hline \multirow[b]{2}{*}{ Country, region } & \multicolumn{2}{|c|}{ Production (million tons) } & \multicolumn{2}{|c|}{ Area (million ha) } & \multicolumn{2}{|c|}{ Yield (t ha $\left.{ }^{-1}\right)$} \\
\hline & 1960 & 2000 & 1960 & 2000 & 1960 & 2000 \\
\hline \multicolumn{7}{|l|}{ Rice } \\
\hline Bangladesh & 14.51 & 35.82 & 8.86 & 10.70 & 1.64 & 3.34 \\
\hline India & 51.86 & 134.50 & 34.13 & 44.60 & 1.52 & 3.01 \\
\hline Nepal & 2.11 & 4.03 & 1.08 & 1.55 & 1.90 & 2.60 \\
\hline Pakistan & 1.54 & 7.00 & 1.21 & 2.31 & 1.31 & 3.03 \\
\hline South Asia & 70.60 & 181.35 & 45.48 & 59.16 & 1.55 & 2.99 \\
\hline \multicolumn{7}{|l|}{ Wheat } \\
\hline Bangladesh & 0.09 & 1.90 & 0.10 & 0.85 & 0.90 & 2.23 \\
\hline India & 11.00 & 74.25 & 12.93 & 26.74 & 0.85 & 2.77 \\
\hline Nepal & 0.14 & 1.18 & 0.11 & 0.65 & 1.20 & 1.82 \\
\hline Pakistan & 4.03 & 21.08 & 4.64 & 8.46 & 0.82 & 2.49 \\
\hline South Asia & 16.24 & 98.41 & 17.57 & 36.70 & 0.84 & 2.33 \\
\hline
\end{tabular}

${ }^{a}$ Adapted from Gupta et al. (9). Year 2000 figures are FAO estimates. 
physiological stresses. Other sources of host resistance involve progenies from wide crosses derivatives, including several synthetic hexaploids. These novel sources of resistance, combined with classical hexaploid wheat and Chinese materials, are probably among the most useful materials available to be used in breeding pro-

Table 2. Average area under disease progress curve (AUDPC), yield $(\mathrm{kg} / \mathrm{ha})$, and days to heading observed in the 9th Helminthosporium Monitoring Nursery in eight locations in the Gangetic Plains in 2001

\begin{tabular}{|c|c|c|c|}
\hline Genotype $^{\mathbf{a}}$ & AUDPC & $\begin{array}{c}\text { Yield } \\
\text { (kg/ha) }\end{array}$ & $\begin{array}{l}\text { Days to } \\
\text { heading }\end{array}$ \\
\hline SW 89-5422 & 229 & 4,125 & 117 \\
\hline NL 785 (Chirya 7) & 215 & 3,822 & 118 \\
\hline Chirya 7 & 216 & 3,836 & 118 \\
\hline Yangmai \#6 & 216 & 3,789 & 117 \\
\hline PBW373 & 240 & 3,917 & 121 \\
\hline KAN/6/COQ/F61.701//CNDR/OLN/4/PHOS/MRNG/... & 273 & 4,197 & 114 \\
\hline Achyut & 285 & 4,109 & 120 \\
\hline ALTAR-84/AE. SQUARROSA(224)//*YACO & 287 & 4,363 & 116 \\
\hline BARKAT/KVZ & 288 & 4,219 & 113 \\
\hline BL2029 & 291 & 3,815 & 117 \\
\hline BL1724 (= PARA2//JUP/BJY/3/VEE\#5/JUN/4/NAC) & 298 & 3,797 & 118 \\
\hline BL1918 & 307 & 4,050 & 113 \\
\hline BL2007 & 310 & 4,415 & 116 \\
\hline $\mathrm{COQ} / \mathrm{F} 61.70 / \mathrm{CNDR} / 3 / \mathrm{OLN} / 4 / \mathrm{PHO}$ & 310 & 4,022 & 114 \\
\hline K 8027 & 312 & 4,413 & 122 \\
\hline BL 1813 (= Galvez/Milan) & 322 & 4,671 & 114 \\
\hline GOURAB (= TURACO/CHIL) & 331 & 4,171 & 113 \\
\hline Pfau/Vee\#5 & 348 & 3,704 & 119 \\
\hline Bow/Buc//Bul & 352 & 3,656 & 116 \\
\hline BL1883 & 356 & 5,078 & 115 \\
\hline Ning 8201 & 357 & 3,548 & 115 \\
\hline K 7 & 358 & 4,361 & 116 \\
\hline Chirya 1 & 364 & 3,943 & 116 \\
\hline Kanchan & 366 & 4,034 & 112 \\
\hline PRL/TONI & 385 & 4,501 & 115 \\
\hline ALTAR-84/AE. SQUARROSA(219)//2*Seri & 390 & 3,909 & 117 \\
\hline BL1884 (= NL251/Ning8319//BL1022) & 414 & 4,380 & 117 \\
\hline Ciano 79 & 455 & 3,999 & 115 \\
\hline RR21 (= Sonalika; local check/susceptible) & 540 & 3,837 & 111 \\
\hline Raj 3765 & 542 & 3,603 & 114 \\
\hline$P$ & $<0.01$ & $<0.01$ & $<0.01$ \\
\hline $\operatorname{LSD}(P<0.05)$ & 59 & 406 & 0.97 \\
\hline $\mathrm{CV} \%$ & 25.4 & 14.3 & 1.8 \\
\hline
\end{tabular}

${ }^{\mathrm{a}} \mathrm{LSD}=$ least significant difference; $\mathrm{CV}=$ coefficient of variance.

Table 3. Wheat genotypes among genetic stocks observed in Bhairhawa (Nepal) in 2001 with a particularly low Helminthosporium leaf blight (HLB) level ${ }^{\mathrm{a}}$

\begin{tabular}{|c|c|c|c|}
\hline \multirow[b]{2}{*}{ Parentage } & \multirow{2}{*}{$\begin{array}{c}\text { Heading } \\
\text { date }^{\mathrm{b}}\end{array}$} & \multicolumn{2}{|c|}{$\begin{array}{c}\text { Diseases } \\
\text { (15 March 2001) }\end{array}$} \\
\hline & & HLB & Leaf rust ${ }^{c}$ \\
\hline MILAN/SHA7 & $1 \mathrm{Mar}$ & 51 & 0 \\
\hline SW89-3060 & $8 \mathrm{Mar}$ & 51 & TMS \\
\hline SW89-3064 & 5 Mar & 51 & 0 \\
\hline SW89-5422 & $1 \mathrm{Mar}$ & 51 & 5MR/MS \\
\hline TURACO/CHIL//PRINIA & 4 Mar & 51 & 0 \\
\hline UP 2472 & 13 Mar & 51 & 0 \\
\hline CHIRYA-7 & 1 Mar & 52 & 0 \\
\hline Mayoor = CS/A.CURV.//GLEN/3/ALD/PVN (= HLB25) & 6 Mar & 52 & TS \\
\hline DL153-2 & 4 Mar & 71 & 0 \\
\hline GISUZ/SABUF & 3 Mar & 71 & 0 \\
\hline K9606 & $8 \mathrm{Mar}$ & 71 & 0 \\
\hline SERI82//VEE"S"/SNB"S"/3/ LAJ3302/TURACO//TURACO & 6 Mar & 71 & 0 \\
\hline TRAP\#1/BOW//CBRD & 9 Mar & 71 & 0 \\
\hline WEAVER/JAKANA & 9 Mar & 71 & 0 \\
\hline BL 2047 = DANIAL88/HLB25//NL297 & $27 \mathrm{Feb}$ & 72 & 0 \\
\hline CHIRYA-3 & $28 \mathrm{Feb}$ & 72 & 0 \\
\hline DOVIN-2 & 3 Mar & 72 & TMR \\
\hline NING8201 & $28 \mathrm{Feb}$ & 72 & $10 \mathrm{MS}$ \\
\hline RR21 (Syn. Sonalika) (local check/susceptible) & $25 \mathrm{Feb}$ & 99 & $40 \mathrm{~S}$ \\
\hline
\end{tabular}

\footnotetext{
${ }^{\text {a }}$ HLB ranging from 51 to 72 on a 00 -to-99 double-digit scale.

${ }^{\mathrm{b}}$ Heading date in March or February.

c $0=$ no visible infection, $10=10 \%, \mathrm{~T}=$ trace, $\mathrm{MR}=$ moderately resistant, $\mathrm{S}=$ susceptible, $\mathrm{MS}=$ moderately susceptible.
}

grams (3). As a result of coordinated efforts between national wheat improvement programs in South Asia and CIMMYT for the last 30 years, progenies of crosses made in the region also emerge as genotypes with improved resistance to foliar blight $(16,25)$. The best entries are sent to CIMMYT's germ plasm bank in Mexico and are included in the main breeding program (2).

Direct introduction of resistant materials, either through CIMMYT international nurseries or other collaborations, and genotypes identified during prebreeding, are combined with the pool of locally adapted materials. Recent procedures using three-way crosses in Nepal provided acceptable resistance and adapted progeny $(1,22)$. However, due to the need to increase wheat production in marginal areas where the yield gap between farmers' fields and experiment stations is still very high, a new regional effort was initiated to specifically promote materials targeted toward warmer areas. The Eastern Gangetic Plain Screening Nursery, organized in 1997, includes a set of 150 entries proposed by national program breeders who share their best advanced lines for testing across hot-spot locations. Data are summarized by CIMMYT's regional office and returned to cooperators (15).

HLB symptoms develop so quickly that it may be difficult to observe small differences between genotypes; therefore, disease severity is rated at least three times to calculate the AUDPC (6). Interestingly, the best yield performance is not necessarily obtained by entries scoring a low AUDPC. This underlines the importance of general adaptation to the environment, particularly abiotic stresses such as heat. It also confirms that HLB resistance is still moderate and needs further improvement. No source of resistance gives high resistance in early maturing genotypes, although there are several materials combining high yield and low disease infection (Table 4). Better resistance levels in adapted genetic backgrounds may be obtained through the use of careful crossing and selection methods.

After evaluation, the best entries are recycled in the national breeding programs or become part of the Eastern Gangetic Plain Yield Trial before being proposed for release or evaluated directly by farmers through participatory varietal selection at the village level. This method is particularly effective because small farmers are able to give their input and choose themselves among a set of advanced materials before new cultivars are released, thus increasing the chance of adoption of improved genotypes (16).

Crop management. Practical approaches toward controlling foliar blight of wheat in South Asia must take into consideration the sustainability of the whole ricewheat system in order to understand the constraints faced by small farmers. As 
indicated above, several factors as diverse as delayed monsoons and labor shortages affect the rice crop and delay the rice harvest. Unbalanced fertility resulting from inappropriate policies, low input use efficiency, nutrient mining, and a receding water table are other aspects that result in lower yields and a late rice harvest, which leads to late wheat sowing. Yield losses due to late planting are as high as 35 $\mathrm{kg} / \mathrm{ha}$ /day after optimum sowing (9).

It is crucial to favor resource-conserving technologies, allowing farmers to sow wheat early to avoid post-anthesis heat stress and drastic yield reductions (9). Early wheat sowing can be promoted by a range of options such as zero tillage, reduced tillage using a Chinese hand tractor, or surface seeding - a traditional practice found by the farmers themselves in marginal areas of eastern Uttar Pradesh (R. Chand and A. K. Joshi, personal communication) - the effect of which on HLB epidemics is not properly documented. Zero-tillage facilitates early wheat sowing by 5 to 15 days and translates to improved yields to the extent of 10 to $25 \%$ over con- ventional practices. However, early wheat sowing is characterized by higher HLB severity, probably due to the high relative humidity and residual soil moisture that prevails at the beginning of the wheat season. In 2002, we observed that AUDPC could increase by as much as $30 \%$ in some cultivars sown 15 days earlier. Thus, even though yield increases with early sowing after adopting resource-conserving technologies, there might be trade-offs due to lack of resistance to HLB. Yet, it demonstrates that further gains in productivity still can be expected by genetic improvement of disease resistance.

There is a growing body of evidence that stresses increased yields losses due to HLB. Studies conducted in Nepal from 2000 to 2002, on the experiment station and in farmers' fields at Rampur and Manara (tarai), comparing plots sprayed with fungicide with untreated ones, showed that yield losses due to HLB could be as high a $34 \%$ when no chemical fertilizer was applied, but were $17 \%$ when the recommended level of fertilizer $\left(\mathrm{N}, \mathrm{P}_{2} \mathrm{O}_{5}\right.$, $\left.\mathrm{K}_{2} \mathrm{O}=120-60-30\right)$ was used. Similarly, losses due to disease increased from $14 \%$ to more than $19 \%$ when supplementary irrigation was not available and physiological stress was higher (23).

Recent studies of long-term trials in Nepal showed the important role of potash in reducing HLB infection levels. Potassium prolongs the canopy's stay-green character Many locations in South Asia present potassium deficiencies, and yet most farmers do not apply this nutrient for several socioeconomical reasons. The AUDPC decreased by $50 \%$ when $40 \mathrm{~kg}$ of $\mathrm{K}_{2} \mathrm{O}$ was applied in deficient soil (18). Similarly, when farmyard manure (FYM) is applied (10 t/ha), the AUDPC drops by $30 \%$, suggesting not only that FYM contains a significant amount of potassium, but that copious levels of organic matter are beneficial and reduce disease severity.

Seed health. The primary source of foliar blight inoculum is not known; therefore, appropriate management practices that enhance the health of the plant populations are critical. Options for controlling tan spot and spot blotch include diseasefree seed. Results obtained with three fun-

Table 4. Top 20 entries for higher grain yield in the fourth Eastern Gangetic Plain Screening Nursery at 10 locations in the eastern Gangetic plains in 2000-01 ${ }^{\text {a }}$

\begin{tabular}{|c|c|c|c|c|}
\hline Genotype $^{b}$ & GYP & TKW & DH & AUDPC \\
\hline MRNG/BUC//BLO/PVN/3/PJB 815 & 479 & 43 & 79 & 326 \\
\hline CKR/HD2172/8/IAS58/6/KAL//BB/5/ALD/4/OLN/TRM//7C/ALD/7/...(1) & 466 & 39 & 75 & 427 \\
\hline PARUS/HD2329//PARUS & 460 & 40 & 80 & 368 \\
\hline KAUZ/STAR/3/KAUZ/CMH77.308//BAU/4/MILAN & 453 & 38 & 76 & 435 \\
\hline CHIR3/PASTOR & 437 & 39 & 76 & 437 \\
\hline VEE/LIRA//BOW/3/BCN/4/KAUZ & 437 & 40 & 79 & 500 \\
\hline OPATA/RAYON//KAUZ & 437 & 37 & 82 & 316 \\
\hline BAW898 & 432 & 43 & 71 & 362 \\
\hline K 9107 & 432 & 44 & 79 & 415 \\
\hline MUNIA/CHTO/3/PFAU/BOW//VEE\#9/4/CHEN/AE.SQUA//BCN & 432 & 46 & 78 & 342 \\
\hline HUW 533 & 431 & 41 & 80 & 377 \\
\hline CKR/HD2172/8/IAS58/6/KAL//BB/5/ALD/4/OLN/TRM//7C/ALD/7/...(2) & 431 & 39 & 77 & 490 \\
\hline KAUZ//KAUZ/STAR/3/PRINIA/4/MILAN/KAUZ & 429 & 39 & 75 & 371 \\
\hline GEN/KAUZ & 429 & 36 & 82 & 355 \\
\hline MAYOOR/CBRD//CHIR3 & 426 & 36 & 81 & 347 \\
\hline TRACHA-2//CMH76-252/PVN"S" & 426 & 43 & 75 & 429 \\
\hline PVN 76 /BL1022 & 424 & 43 & 72 & 357 \\
\hline CHIR3//OPATA/KILL & 422 & 39 & 78 & 417 \\
\hline W462/VEE/KOEL/3/PEG//MRL/BUC & 422 & 39 & 76 & 247 \\
\hline GOMAM/GRU90-205266 & 421 & 37 & 75 & 435 \\
\hline BHRIKUTI (local check) & 386 & 37 & 77 & 448 \\
\hline RR21 = Syn. SONALIKA (susceptible check) & 361 & 43 & 72 & 694 \\
\hline$P$ & $<0.01$ & $<0.01$ & $<0.01$ & $<0.01$ \\
\hline $\operatorname{LSD}(P<0.05)$ & 78 & 3 & 3 & 116 \\
\hline $\mathrm{CV}(\%)$ & 23.7 & 9.5 & 5.0 & 34.1 \\
\hline
\end{tabular}

${ }^{a}$ Grain yield (GYP, g/plot), thousand-kernel weight (TKW), days to heading (DH), and area under the disease progress curve (AUDPC) based on percent diseased leaf area (16).

${ }^{\mathrm{b}} \mathrm{LSD}=$ least significant difference; $\mathrm{CV}=$ coefficient of variance.

Table 5. Comparison of the effect of three fungicides on emergence, infected seedlings, number of tillers, thousand-kernel weight (TKW), and grain yield in Rampur (Nepal) in 2002 $2^{\mathrm{a}}$

\begin{tabular}{|c|c|c|c|c|c|c|}
\hline \multirow[b]{2}{*}{ Fungicide } & \multicolumn{2}{|c|}{ Emergence } & \multirow[b]{2}{*}{ Infected seedlings $\left(\mathbf{m}^{2}\right)^{b}$} & \multirow[b]{2}{*}{ No. of tillers (2-m row) } & \multirow[b]{2}{*}{ TKW (g) } & \multirow[b]{2}{*}{ Grain yield (t/ha) } \\
\hline & $\mathbf{m}^{2}$ & + Percent & & & & \\
\hline Vitavax-200 & 50.7 & 43.2 & 5.9 & 72.9 & 40.33 & 2.63 \\
\hline Bavistin & 41.3 & 16.3 & 4.6 & 69.4 & 39.63 & 2.44 \\
\hline Simonis Carbendazim & 52.9 & 49.2 & 6.4 & 69.4 & 39.15 & 2.48 \\
\hline Check & 35.4 & $\ldots$ & 4.3 & 59.9 & 38.93 & 2.44 \\
\hline Significance & ** & $\ldots$ & NS & $* *$ & NS & NS \\
\hline
\end{tabular}

a Duveiller et al. 2002 (7). NS = not significant; $* *=P<0.01$.

${ }^{\mathrm{b}}$ As of 28 December 2001. 
gicides available at an affordable price in South Asia (7) are shown in Table 5. These seed treatments mainly target loose smut (Ustilago tritici). Although the effect on early foliar blight symptoms and the number of infected seedlings was nonsignificant, the three fungicides significantly increase the percent emergence and contribute to crop establishment and plant density, two important factors in wheat grown after rice. However, this effect alone does not increase thousand-kernel weight and grain yield, suggesting that external sources of foliar blight inoculum, probably airborne, are overwhelming and play a major role during epidemics.

\section{Conclusions}

Very little is known about the inheritance of resistance genes effective against foliar blight. The task is complicated by the similarity of symptoms induced by two pathogens, most probably triggering different resistance genes. Cooperation among pathologists, breeders, and agronomists will be necessary to ensure sustainable control of foliar blights in South Asia. More research is needed to better understand disease epidemiology and identify new resistant materials. Germ plasm is paramount. Because the disease is rather new, the genetic basis of host resistance to HLB is relatively narrow, and there is a need to broaden the sources of variability. The role of crop rotation and fertilization seems equally important, but the long-term effects of using new resource-conserving cultural practices will need to be monitored. In summary, controlling foliar blight in wheat is complex and requires a holistic approach. It is part of technological packages that make small-scale wheat production more cost effective and sustainable, particularly in warmer areas. Farmers increasingly are involved in this research process, and the whole production system must be considered. Integrated crop improvement for small farmers combining "germ plasm $\times$ environment $\times$ management $\times$ people" more than ever requires a multidisciplinary team effort.

\section{ACKNOWLEDGMENTS}

The author thanks A. McNab for reviewing the manuscript.

\section{LITERATURE CITED}

1. Dubin, H. J., and Duveiller, E. 2000. Helminthosporium leaf blights of wheat: Integrated control and prospects for the future. Pages 575-579 in: Proc. Int. Conf. Integrated Plant Dis. Manag. Sustainable Agric. Vol. 1. D. K. Mitra, ed. Indian Phytopathological Society, New Delhi, India.

2. Dubin, H. J., and Rajaram, S. 1996. Breeding disease resistant wheats for tropical highlands and lowlands. Annu. Rev. Phytopathol.
34:503-526.

3. Duveiller, E. 2002. Helminthosporium blights of wheat: Challenges and strategies for a better disease control. Pages 57-66 in: Advance of Wheat Breeding in China. Proc. First Natl. Wheat Breeding Conf. China Science and Technology Press, Jinan, Shandong, People's Republic of China.

4. Duveiller, E., García, I., Toledo, J., Franco, J., Crossa, J., and Lopez, F. 1998. Evaluating spot blotch resistance of wheat: improving disease assessment under controlled conditions and in the field. Pages 171-181 in: Proce. Int. Workshop Helminthosporium Diseases of Wheat: Spot Blotch and Tan Spot. E. Duveiller, H. J. Dubin, J. Reeves, and A. McNab, eds. CIMMYT, El Batán, Mexico,.

5. Duveiller, E., and García-Altamirano, I. 2000. Pathogenicity of Bipolaris sorokiniana isolates from wheat roots, leaves and grains in Mexico. Plant Pathol. 49:235-242.

6. Duveiller, E., Ortiz-Ferrara, G., Bhatta, M. R., Nagarajan, S., Shekhawat, A. B. S., and Adhikari, B. 2001. Comparison of wheat resistance to Helminthosporium leaf blight at key locations in eastern Gangetic plains of south Asia. Proc. Conf. Role of Resistance in Intensive Agriculture 23:233-237. S. Nagarajan and D. P. Singh, eds. Kalyani Publishers, Ludhiana, India.

7. Duveiller, E., Sharma, R. C., Bhandari, D., Bhatta, M. R., Gharti, D. B., Karki, C. B., Ortiz-Ferrara, G., Sharma, S., Sharma, D., and Shrestha, S. M. 2002. Practical approaches to sustainable foliar blight management in wheat with special reference to rice-wheat systems in the Gangetic plains. Page 13 in: (Abstr.) Fourth Int. Wheat Tan spot and Spot Blotch Workshop, Bemidji, MN

8. Duveiller, E., van Ginkel, M., and Dubin, H. J. 1998. Helminthosporium diseases of wheat: A summary of group discussions and recommendations. Pages 1-5 in: Proc. Int. Workshop on Helminthosporium Diseases of Wheat: Spot Blotch and Tan Spot. E. Duveiller, H. J. Dubin, J. Reeves, and A. McNab, eds. CIMMYT, El Batán, Mexico.

9. Gupta, R. K., Hobbs, P. R., Ladha, J. K., and Prabhakar, S. V. 2002. Resource conserving technologies: Transforming the rice-wheat systems of the Indo-Gangetic plains. APAARI Publication: 2002-1, Bangkok-New Delhi, India.

10. Heisey, P. W., Lantican, M. A., and Dubin, H. J. 2002. Impacts of international wheat breeding research in developing countries, 1966-97. CIMMYT, D.F., Mexico.

11. Hetzler, J., Eyal, Z., Mehta, Y. R., Campos, L. A., Fehrmann, H., Kushnir, U., Zekaria-Oren, J., and Cohen, L. 1991. Interactions between spot blotch (Cochliobolus sativus) and wheat cultivars. Pages 146-164 in: Proc. Int. Conf. Wheat for Nontraditional, Warm Areas, Foz do Iguazu (Brazil). D. Saunders, ed. CIMMYT, Mexico.

12. Hobbs, P., and Morris, M. 1996. Meeting south Asia's future food requirements from ricewheat cropping systems: priority issues facing researchers in the post-green revolution era. NRG paper 96-01. CIMMYT, D.F., Mexico.

13. Kumar, J., Shäffer, P., Hückelhoven, R., Langen, G., Baltruschat, H., Stein, E., Nagarajan, S., and Kogel, K. H. 2002. Bipolaris sorokiniana, a cereal pathogen of global concern: Cytological and molecular approaches towards better control. Mol. Plant Pathol. 3:185-195.

14. Maraite, H., Di Zinno, T., Longrée, H., Daumerie, V., and Duveiller, E. 1998. Fungi associated with foliar blight of wheat in warm ar- eas. Pages 293-300 in: Proc. Int. Workshop on Helminthosporium Diseases of Wheat: Spot Blotch and Tan Spot. CIMMYT, El Batán, Mexico.

15. Ortiz-Ferrara, G., Bhatta, M. R., Duveiller, E., and Budhathoki, B. 2002. Results of the 4th Eastern Gangetic Plains Screening Nursery 2000-2001. NARC/CIMMYT, Kathmandu, Nepal.

16. Ortiz-Ferrara, G., Bhatta, M. R., Pokharel, T., Mudwari, A., Thapa, D. B., Joshi, A. K., Chand, R., Muhammad, D., Duveiller, E., and Rajaram, S. 2001. Farmer participatory variety selection in South Asia. Pages 33-37 in: Research Highlights of the CIMMYT Wheat Program Research 1999-2000, D.F., Mexico.

17. Prabhu, A. S., and Prasada, R. 1966. Pathological and epidemiological studies on leaf blight of wheat caused by Alternaria triticina. Indian Phytopathology 19:95-112.

18. Regmi, A. P., Ladha, J. K., Pasuquin, E. M., Pathak, H., Hobbs, P. R., Shrestha, L. L. Gharti, D. B., and Duveiller, E. 2002. The role of potassium in sustaining yields in a longterm rice-wheat experiment in the IndoGangetic plains of Nepal. Biol. Fertil. Soils 36:240-247.

19. Rosegrant, M., Agcaoili-Sombilla, M., and Perez, N. D. 1995. Global food projections to 2020: implications for investment. Food, Agriculture, and the Environment Discussion Paper 5. International Food Policy Research Institute, Washington D.C.

20. Rotem, J. 1994. Alternaria triticina and A. alternata on wheat. Pages 248-250 in: The Genus Alternaria: Biology, Epidemiology and Pathogenicity. American Phytopathological Society Press, St. Paul, MN.

21. Saari, E. E. 1998. Leaf blight diseases and associated soilborne fungal pathogens of wheat in South Asia and Southeast Asia. Pages 37-51 in: Proc. Int. Workshop on Helminthosporium Diseases of Wheat: Spot Blotch and Tan Spot. E. Duveiller, H. J. Dubin, J. Reeves, and A. McNab, eds. CIMMYT, El Batán, Mexico.

22. Sharma, R. C., and Bhatta, M. R. 1999. Inheritance of field resistance to spot blotch in three wheat crosses. J. Inst. Agric. Animal Sci. (Nepal) 19-20:111-118

23. Sharma, R. C., Kandel, Y. R., Duveiller, E., and Shrestha, S. M. 2002. Characterization of Helminthosporium leaf blight resistance in wheat at different growth stages. Page 32 in: (Abstr.) Fourth Int. Wheat Tan spot and Spot Blotch Workshop, Bemidji, MN.

24. Sharma, R. C. Shrestha, S. M., and Duveiller, E. 2002. Incidence of Bipolaris sorokiniana and Pyrenophora tritici-repentis on wheat in the lowlands of Nepal. Page 34 in: (Abstr.) Fourth Int. Wheat Tan spot and Spot Blotch Workshop. Bemidji, MN.

25. Singh, G., Tripathi, S. C., Tyagi, B. S., Shohan, J., and Nagarajan, S. 2002. Promising wheat varieties for eastern India and warmer regions of India. Tech. Bull. 3. Directorate of Wheat Research, Karnal, India.

26. Singh, R. B., Kumar, P., and Woodhead, T. 2002. Smallholder farmers in India: food security and agricultural policy. RAP Publication 2002/3. Bangkok, Thailand.

27. van Ginkel, M. and Rajaram, S. 1998. Breeding for resistance to spot blotch in wheat: global perspective. Pages 162-170 in: Proc. Int. Workshop on Helminthosporium Diseases of Wheat: Spot Blotch and Tan Spot. E. Duveiller, H. J. Dubin, J. Reeves, and A. McNab, eds. CIMMYT, El Batán, Mexico. 